\title{
Better Education at Ishik University Preparatory School with Extracurricular Activities
}

\author{
Yunus Yildiz \\ Ishik University, Department of Languages, Suleimania, Iraq \\ E-mail: yunus.yildiz@ishik.edu.iq
}

\author{
Doi:10.7575/aiac.alls.v.6n.4p.158 \\ URL: http://dx.doi.org/10.7575/aiac.alls.v.6n.4p.158
}

Received: 05/04/2015

Accepted: 08/06/2015

\begin{abstract}
It cannot be said that education today in institutions is better than the previous century. Because in the past, students' mind was not as full of time-consuming things like spending enormous time in front of a computer or a television as today. Subsequently, teachers used to concentrate their job well and students used to focus on the study better because there was nothing serious except studying. On the other hand, it can be said that the youth today are not eager to learn as yesterday. Because of the fact that they are economically free and supported, they do not worry about failing in the exams supposing that they can possess the questions somehow easily and pass the exams. As a result, they think that whatever they want, they can simply gain without pain. Doing homework or extra studies are a torture from students' perspective. As lecturers we are we have to find much more tactics to motivate students in this education era. Hence, extracurricular activities might play a great role for motivating them to study and on their study achievement if they are used in institutions effectively. In my research article educators' observations and extracurricular activities' positive impact on weak language learners will be mentioned.
\end{abstract}

Keywords: Extracurricular, impact, observation, education, achievement

\section{Introduction}

Lecturers' responsibility today is much more difficult than comparing to last decades. It is indeed hard to draw not only the instructors but also the students into teaching and learning process. Educators should be sophisticated, skillful, and good at computer and managing skills. Moreover, educators should be more motivated, patient and motivators to cause a great impact on students' study performance.

As I have been teaching for about 17 years in all level of institutions to teach English to learners as a foreign language, it can be said that students are given too much homework to prepare in very short time. In the beginning of academic semester, it seems to be fun for language learners with a great craving to hand their homework in time. However, doing homework or studying English turns into a nightmare or a torture some weeks later due to educators' experience. Therefore, studying and fulfilling homework and keeping up in the same speed to learn English are difficult and challenging exertion for students. In the end, students' appetite to study is lost. Especially, if you are a lecturer in a very hot land and the academic year is only 24 weeks for preparatory school students, you will have to find many technics or tactics to draw students' mind to lessons. The fact is that, there is an intensive curriculum in the schedule and language teachers have to cope with it. Moreover, educators are supposed to take students from starter level to intermediate level to make them successful students in their educational departments. Frankly, it is out of standards and reality. But, according to year by year Ishik University Preparatory School students' academic success performance chart shows that students are approximately $\% 85$ successful in the end of (24) weeks education and only \% 15 of students are called to summer school that takes one month and $\% 90$ of summer school students succeed in the final exams. It demonstrates that Ishik Preparatory School somehow expands students' knowledge of English to an efficient level before the next academic year and can be described as a successful institution.

There are many factors that support the belief that Ishik University is a successful educational institution. According to teachers' observations, what relies beyond this fact can be explained by teachers and students' motivation, their close relationship and continuous education without interval. To succeed in this attempt some vital actions below should be taken into account.

1-Weeekly summit with administration, level coordinators and lecturers,

2-Motivating lecturers as giving targets and controlling them in weekly summits,

3-Assigning class supervisors as extracurricular activity organizers for each language class,

4-Organizing extracurricular activity programs after lessons,

5-Motivational picnics both for lecturers and students should be arranged twice a year. 


\subsection{Weekly Summits}

Summits are the first requirements for reaching the right decision and two lots of knowledge are better than one. Therefore, gathering once a week and sharing and contribution are something beneficial in education year in need. The role of summits in preparatory school is crucial for administration staff and level instructors to check if the language classes are taking the course in the same pace. Because, there might be some lecturers that teaching fast and the techniques that they use might be out of date. But, there is no need to take the summits too long as it is high time to take an action instead of discussing and talking about matters.

\subsection{Motivating Lecturers}

As educators working in prestigious institutions; the way that they talk, wear or behave are all the time observed in and out of the building. As a matter of fact, educators should reflect all universal etiquette while working and teaching (Sünbül, 1996). On the other hand, as being humans, it is hard to control our behavior in case of misbehavior or disrespect coming from students or/and educators' personal problems that run in their mind while teaching (Dörnyei, Z., \& Kubanyiova, M. 2014). This kind of stuff is demotivating factor for lecturers and affects the way the lecturer teaches students. Considering this issue, level coordinators and administration should think about some responsibilities to give lecturers like presentation lessons once a month and giving innovative comments to develop the lecturers' quality of teaching, and organize some seminar programs in short holidays. Because, the more the lecturers are busy at work, the better they give themselves to work. However actively lecturers work at preparatory school, it is substantial for the administrative to have a good communication with the staff.

In addition, to handle this issue, educators can be taken to one week vacation in resort centers with their families either in Kurdistan or abroad on Nawroz holiday. Relaxation in the big Nawroz interval can lighten the burden that educators carry.

\subsection{Assigning class supervisors as extracurricular activity organizers}

Teaching students have to be formal and fair in class but it is difficult and time-consuming to reach and educate all students at once. Therefore, it is essential to organize out of school activities to push students to learn English. This action can be led either by the lecturers or some capable and skillful students. Most of all, preparatory school administration should persuade the lecturers as talking about the importance of extracurricular activities. Classes should have supervisors and students should be convinced that by joining in ECAs which are led by the supervisors will take them into English world. Meanwhile, lecturers should be supported financially to arrange activities.

\subsection{Organizing extracurricular activity programs after lessons}

Parents at home, lecturers at university face difficulties to make students learn. Because, students are usually embedded in face book or internet and after school, they are in the intention of leaving for home. They are given homework regularly but usually almost half of the class does not fulfill. They come to school early and copy their homework from other students if they know that they will be graded. As a result, in the beginning of the year, there should be meetings for students and parents separately to demonstrate the preparatory school system and expectations and presentations about extracurricular activities at preparatory school and their roles in learning English should be explained well. While first impression is known important, by taking precautions students can be embedded in ECA programs when it is planned easily.

Extracurricular activities can be formal or informal. If it is organized in the school building relating to course subject, it is formal and sometimes called co-curricular activities. However, if it is something different such as playing tennis, football or an activity out of school like going to café or having picnics in the environment can be named informal. Whichever the activity that lecturers do with students should be led in English. Lingua franca should be just English. From the experiences and also researches, it can be stated that participation in ECAs contribute to students connect to the school community. Students see themselves members of the school and become devoted to lecturers as well. Programs prevent dropouts and teach students how to manage time. If students are satisfied with the things that happening around them and see the lecturers doing their best for their better learning, school atmosphere will change, students will learn better and will be in the intention of joining extracurricular programs staying for much more time after lessons. And after all, positive atmosphere will be created in the institution.

\subsection{Motivational picnics}

Activities at university are memorable moments in students' life. To motivate students and the staff, it is crucial to have a picnic once a term (Akay, C., \& Anvarovich, A. A. 2015). The warm atmosphere between the lecturers and students can be supplied with picnics and "the happier people at university, the better results at school can be gained" can be said. Especially, picnics with students can be organized at the beginning of the year and before Nawroz holiday starts. By the means of healthy community, students will have a chance to have information about the lecturers' attitudes to students and will improve their communication competence.

\subsection{Extracurricular Activities' Positive Impact on Weak English Learners}

Lots of educators say that ECAs have positive impacts on students' learning. To make sure of this idea some ECAs were organized at Ishik University Suleimania Preparatory School. In the beginning of the first month of preparatory school nothing was done as ECAs. Because we needed time to see students' capability and capacity to absorb the language they were learning. At the end of the one month language education, it appeared that there were two groups in the classroom as best learners and weak learners. Students were all as control group members for a month. In the 
beginning of the second month, I selected only the students who were poor at English (just five students) as experiment group members for extracurricular activity program and we started testing and analyzing ECA for 40 minutes before the lessons at school five days a week. The students who had basic problems in the form of to be verb, helping verbs, pronouns, adjectives and adverbs, performed great interest and corrected their lacks after regular classes. Our activity program lasted just a month and now students are hopeful to achieve in the final exam. This ECA program caused students to discover and improve their abilities, connected them to school, taught them to work in a team and to use time efficiently and built up self-esteem. This is the proof that co-teaching activity programs will have positive impact on weak English language learners (Carless, D., \& Walker, E. 2006).To handle this issue in Suleimania Ishik Prep School has not been hard to lead because of the number of students and their craving to learn English language.

\section{Method}

As the number of students in Ishik University Suleimania branch is not many; only (18) students of preparatory school students participated in the filling the survey. The number of male students was (12) and the number of female students was (6). Their mean age ranged from (18) to (25).

\subsection{Measures and Procedure}

The data was obtained from the 10- question questionnaire. The answers included (3) scales as; a) yes b) no c) I do not know.

All students were in an English class. They were told that they would answer survey questions and the answer they gave to the questions would have a great role to arrange an ECA. After analyzing survey questions, new plans would be arranged to develop their English. Survey was delivered and students were allowed to select the best alternative. Some points were explained during their selection. Honest answers were expected. Because according to gained data, the plan would start.

\section{Result}

As many scholars indicate that ECAs can lead students to higher educational success, help students to get better grades (Marsh, 1992 ) and students get higher scores in tests (Gerber, 1996); I have also come to the point that the students who are as constant participants to ECAs are much more dynamic and eager to learn than non-participants (see Appendix 1). Moreover, they are also sure that joining in ECAs brings them satisfaction and feel that they learn better and also students explain that ECAs make preparatory school unique comparing other institutions. Analyzing the survey questions we can say that students are happy to participate ECAs and they can learn better on condition that they are in ECAs and the best way to improve their English is participation in ECAs.

\section{Conclusion}

Extracurricular activities are inevitably important in students' language learning process. They connect students to school and students can get good communication with lecturers. They are encouraged to learn in a warm, informal atmosphere and have good friendship with their peers. On the other hand, to make all these things come true is up to the supervisors or ECA coachers' limitless effort and patience. Moreover, we cannot separate school education with extracurricular activities because they are a significant part of education (Marsh, H. W., \& Kleitman, S. 2002).

\section{References}

Akay, C., \& Anvarovich, A. A. (2015). The Role of Teachers' Motivation on the Language Learner's Strategies. Asian Journal of Humanities and Social Studies, 3(1).

Carless, D., \& Walker, E. (2006). Effective team teaching between local and native-speaking English teachers. Language and Education, 20(6), 463-477.

Dörnyei, Z., \& Kubanyiova, M. (2014). Motivating learners, motivating teachers: Building vision in the language classroom.

Gerber, S. B. (1996). Extracurricular activities and academic achievement.Journal of Research \& Development in Education.

Marsh, H. W. (1992). Extracurricular activities: Beneficial extension of the traditional curriculum or subversion of academic goals?. Journal of educational psychology, 84(4), 553.

Marsh, H. W., \& Kleitman, S. (2002). Extracurricular school activities: The good, the bad, and the nonlinear. Harvard Educational Review, 72(4), 464-515.

Sünbül, A. M. (1996). Öğretmen niteliği ve öğretimdeki rolleri. Kuram ve Uygulamada Eğitim Yönetimi Dergisi, 2(4), 597-608. 


\section{A1- QUESTIONNAIRE ITEM RESULTS}

\begin{tabular}{|c|c|c|c|}
\hline ITEMS & YES\% & $\mathrm{NO} \%$ & $\begin{array}{c}\text { I HAVE NO } \\
\text { IDEA } \%\end{array}$ \\
\hline 1-Do you like the atmosphere you have in Ishik Preparatory School? & 88 & 6 & 6 \\
\hline 2-Is only coming to school enough for your education? & - & 100 & - \\
\hline 3-Is it good to have extracurricular activities before or after lessons? & 94 & 6 & - \\
\hline 4-Do extracurricular activities help you to improve your English? & 94 & - & 6 \\
\hline 5-Do you think if school should go with extracurricular activities? & 88 & 6 & 6 \\
\hline 6-Do you think that you learn more in extracurricular activities than studying at home? & 88 & - & 12 \\
\hline $\begin{array}{l}\text { 7-Do you think that students should deal with extracurricular activities every day for } \\
\text { some time? }\end{array}$ & 72 & 12 & 16 \\
\hline 8-Is learning English fun with ECAs? & 94 & - & 6 \\
\hline 9-Do you enjoy language oriented ECAs in preparatory school? & 84 & & 16 \\
\hline 10-Do you get motivated by ECAs in learning English process? & 88 & 6 & 6 \\
\hline
\end{tabular}

\section{Dear student}

\section{A2-QUESTIONNAIRE FORM}

This data collection paper is prepared to find answer to the questions like what should be done and what is expected from your point of view from lecturers for your better learning English education in the field of extracurricular activities. It is expected from you to select the best alternative on your own. Think about the questions seriously and choose the answer that true for you. You should provide your name on the list. Because, according to your needs actions will be done.

\section{QUESTIONNAIRE ITEMS}

1-Do you like the atmosphere you have in Ishik Preparatory School?
a) yes
b) no
c) I have no idea

2-Is just coming to school for your education enough?
a) yes
b) no
c) I have no idea

3-Is it good to have extracurricular activities before or after lessons?
a) yes
b) no
c) I have no idea

4-Do extracurricular activities help you to improve your English?
a) yes
b) no
c) I have no idea

5-Do you think "Ishik University Preparatory School" should go with extracurricular activities?
a) yes
b) no
c) I have no idea

6-Do you think that you learn more in extracurricular activities than studying at home?
a) yes
b) no
c) I have no idea

7-Do you think that students should deal with extracurricular activities every day for some time?
a) yes
b) no
c) I have no idea

8-Is learning English fun with ECAs?
a) yes
b) no
c) I have no idea

9-Do you enjoy language oriented ECAs in preparatory school?
a) yes
b) no
c) I have no idea

10-Do you get motivated by ECAs in learning English process?
a)
yes
b) no
c) I have no idea 